Шедяков В. Е., д.с.н., к.э.н., доцент

независимый исследователь

г. Киев, Украина

DOI: https://doi.org/10.30525/978-9934-26-018-6-10

\title{
ТРАНСФОРМАЦИИ \\ ПОЛИТИКО-ЭКОНОМИЧЕСКОГО ПРОСТРАНСТВА: ОБЩЕСТВО И ГОСУДАРСТВО
}

Задачи повышения уровня экономической безопасности готовят новые формы ответов в диапазоне и акторов, и целей, и средств. В частности, требуется осуществить поиск путей и возможностей оптимизации взаимодействия общества и государства. Баланс самонастройки и сознательного реформирования социально-экономического механизма изменчив. Его динамизм и направленность резко смещаются при кардинальных политикоэкономических трансформациях. Тем более - при переменах парадигмального уровня и глобального масштаба. С одной стороны, для человечества всё важнее просоциальные развитие и реализации сугубо индивидуальных комплексов одарённости каждого. С другой, - от упований на регулятивные возможности рыночной стихии осуществлён переход к ориентации на расчёт потребительских ниш, маркетинговые планирование, стимулирование и управление. Модели «свободного ценообразования», «рыночной конкуренции», «частной собственности» играют роль исключительно средств идеологической апологетики и отвлечения внимания от реальных экономических процессов. Череда кризисов дополнительно стимулирует действия государств [1-4].

Действие закона неравномерности исторического развития приводит к постоянной смене лидеров развития в ойкумене, видоизменяя представления о должном и желательном и обостряя конфликтность между культурно-цивилизационными мирами и внутри них, что и обеспечивает конкуренцию подходов и многобразие поисков ответов на исторические вызовы. Состязание между странами и культурно-цивилизационными мирами в 
рамках «коридора свободы» определённого миропорядка при выходе за его пределы сменяется ожесточённой конкуренцией за формирование из хаоса нового порядка мироустройства на основе своей институциональной памяти и практико-теоретической парадигмы, выливаясь в борьбу за возможность возглавить / использовать в своих интересах возникающие возможности. И сегодня, с одной стороны, воспроизводство ойкумены накрепко связало культурно-цивилизационные миры, формой чего и стало соотношение конкурентности / состязательности и партнёрства / кооперации с той или иной степенью комплиментарности или же, напротив, враждебности. С другой же, - общественное воспроизводство на прежних, произошедших из западного капитализма, отношениях, достигло своих пределов [5-8]. Очевидно, что и политико-экономическая модель либеральной демократии убедительно доказала несостоятельность перед лицом коренных проблем общественного развития, выродившись в ряд социальных патологий. Естественно, при рассыпании постглобальностью привычного международного разделения труда и переходе к жёсткой (в т.ч. экономической) защите суверенитета активно создаются альтернативные варианты и представлений о будущем, и модели достижения национальной безопасности, связанные с высоким уровнем социальных обязательств.

Период активных трансформаций усиливает инновационные поиски народов, открывая как ошибочные, так и оптимальные решения [9-11]. Выращивание благотворного для желательных перемен общественного пространства и кластеров положительных сдвигов - важнейшие составляющие элементы стратегии стимулирования развития. Перспективы политико-экономического развития определяющим образом создаются соответственно, во-первых, вектору системообразующих отношений труда, собственности и управления и, во-вторых, динамике человеческого фактора, подборе продуктивных вариантов сочетания разноуровневых интересов при росте эффективности производства. Вместе с тем, задачи максимизации творческой 
активности (в частности, обеспечения просоциальных развития и раскрытия способностей населения) требуют как адекватного государственного курса, так и развития общественного пространства. С одной стороны, участие в труде должно гарантировать материальное благосостояние и обеспечивать высокий социальный статус. С другой стороны, - только личный труд, индивидуальное участие в общем творчестве и воспринимается справедливым фактором дифференциации благосостояния и авторитета / престижа. Соответственно, меняется соотношение государственности и общественности; в частности, серьёзной задачей разумной инициативы и творческой активности становится укрепление государственности, своего культурноцивилизационного мира и его базовых ценностно-смысловых комплексов. Таким образом, историей сформирован запрос на государственно-частное партнёрство, в т.ч. - в вопросах социальной инженерии, где грани допустимого и разумного, соподчинённость целей и средств тоже подвержены трансформациям [12-14].

\section{Литература:}

1. Якість економічного зростання / Томас В., Дайламі М., Дарешвар А. та ін. Київ : Основи, 2002. 350 с.

2. Шедяков В.Е. Социокультурные коммуникации как фактор целостности экономического структурирования и регулирования. Проблеми системного nідходу в економіці. 2019. № 3 (71). Ч. 1. С. 22-28. DOI: https://doi.org/ 10.32782/2520-2200/2019-3-3.

3. Шедяков В.Е. Социокультурный капитал как условие активизации производительных сил общества. Актуальні проблеми філософії та соиіологіï. 2015. № 5. C. 212-215.

4. Shedyakov V. Economics of development or dying away: the role of social and information technologies. Development of modern science: the experience of European countries and prospects for Ukraine / scient. ed. \& project dir. A. Jankovska. Riga: Baltija Publishing, 2019. P. 289-307. DOI: https://doi.org/ 10.30525/978-9934-571-78-7_16

5. Шедяков В.Е. Возможности и риски эпохи: научно-исследовательская рефлексия - рефлексивное управление - рефлексивная модернизация. Management of modern socio-economic systems / ed. by J. Žukovskis, K. Shaposhnykov. Kaunas : Baltija Publishing, 2017. Vol. 1. P. 201-218. 
6. Бузгалин А.В., Колганов А.И. Пределы капитала: методология и онтология. Москва : Культурная революция, 2009. 680 с.

7. Шедяков В.Е. Постглобальные возможности и угрозы: диапазон решений. Economic Development: Global Trends and National Peculiarities / ed. by A. Pawlik, K. Shaposhnykov. Kielce: Baltija Publishing, 2020. P. 261-275. DOI: https://doi.org/10.30525/978-9934-588-61-7-18.

8. Buchanan P.J. The Death of the West. USA : St. Martin's Press, 2001. 320 p.

9. Шедяков В.Е. Переходный период: актуальные возможности развития. Scientific Collection «InterConf». 2020. № 3 (36) : Intern. Forum: Problems \& Scient. Solutions: with the Proceed. of VII Intern. Scient. \& Pract. Conf. «Challenges in Science of Nowadays» (November 26-28, 2020). Washington. P. 572-579.

10. Шедяков В.Е. Обогащение закономерностей переходного периода конкретикой случайного. Labyrinths of Reality. 2020. Iss. 4 (9) : Collection of scient. works (based on materials of IX Intern. Scient. \& Pract. Conf. (October 14-15, 2020). Montreal. P. 6-9.

11. Шедяков В.Е. Осуществление парадигмальных трансформаций: сорезонирование стратегии, тактики и оперативного искусства в управленческих композициях. Development and modernization of social sciences: experience of Poland and prospects of Ukraine / Maria Curie-Sklodowska University. Lublin : Baltija Publishing, 2017. P. 282-307.

12. Шедяков В.Е. Экономическое мышление за пределами либерализма. Содружество. 2016. № 5. С. 90-94.

13. Шедяков В. Е. Диапазон эффективной социальной инженерии во время форсированных преобразований. Суспільні науки: напрямки та тенденції розвитку в Украӥні та світі: Матер. Міжнар. наук.-практ. конф. Одеса, 21-22 липня 2017. С. 77-82.

14. Шедяков В.Е. Кластеры как локомотивы социально-экономического развития. Cluster Policy of Innovative Development of the National Economy: Integration and Infrastructure Aspects / ed. by S. Smerichevska. Poznań: WSPIA, 2020. P. 129-143. 